\title{
EVALUASI PENERAPAN AKUNTANSI PERSEDIAAN OBAT BERDASARKAN PSAK NO. 14 PADA PT. CEMPAKA INDAH MURNI MANADO
}

\author{
Gleidys Audina Hengkeng ${ }^{1}$, Sifrid S. Pangemanan ${ }^{2}$, Jessy D. L.Warongan ${ }^{3}$ \\ 1, 2,3Jurusan Akuntansi, Fakultas Ekonomi dan Bisnis, Universitas Sam Ratulangi, Jl. Kampus Bahu, Manado, \\ 95115, Indonesia \\ E-mail: gleidysaudinagmail.com
}

\begin{abstract}
Inventory is very important for the survival of the company, the company must be able to estimate the amount of inventory it has. This study aims to determine the analysis of the application of drug inventory accounting based on PSAK No.14 at PT. Cempaka Indah Murni Manado engaged in the distribution of medicines. The analytical method used in this research is a qualitative descriptive method then the conclusion of the recording method applied in recording merchandise inventory is a computerized perpetual method, while the inventory valuation method uses the FIFO (First In First Out) method. The company does not recognize the purchase costs and conversion costs, the company only recognizes other costs such as shipping costs / shipping costs, incoming transfers, and sales costs because the products sold at PT. Cempaka Indah Murni Manado was sent from the head office in Surabaya. The results showed that the application of accounting for drug supplies was carried out. PT. Cempaka Indah Murni Manado is not in accordance with PSAK No. 14.
\end{abstract}

Keywords: inventory accounting; PSAK 14; recording; valuation method

\section{PENDAHULUAN}

Persediaan merupakan salah satu sumber daya dalam perusahaan yang memerlukan pengalokasian dan penilaian yang tepat. Hal ini sangat membantu manajemen dalam melakukan pengambilan keputusan, baik itu keputusan yang berkaitan dengan laba maupun keputusan lain yang berpengaruh dalam perkembangan keuangan perusahaan. Persediaan pada umumnya memiliki nilai yang relatif besar dari akiva lancar atau bahkan seluruh aset perusahaan. Perusahaan dagang sebagai entias bisnis yang membeli barang untuk dijual kembali, maka pengelompokkan persediaan hanya pada persediaan barang dagang. Pada perusahaan manufaktur dimana entitas bisnis ini mengelola bahan baku menjadi barang jadi maka persediaan dikelompokkan dalam persediaan bahan baku, persediaan barang dalam proses, persediaan barang jadi, persediaan barang penolong dan persediaan perlengkapan.

Pernyataan Standar Akuntansi (PSAK) Nomor 14 yang bertujuan untuk mengatur perlakuan akuntansi untuk persediaan. Persediaan adalah aset yang tersedia untuk dijual dalam kegiatan usaha biasa, dalam proses produksi penjualan tersebut atau dalam bentuk bahan atau dalam bentuk perlengkapan untuk digunakan dalam proses produksi atau pembelian jasa.PSAK Nomor 14 dijelaskan mengenai perlakuan akuntansi untuk persediaan, ruang lingkup yang dapat digolongkan sebagai persediaan, pengukuran persediaan, biayabiaya yang mempengaruhi persediaan, dan juga mengenai pengungkapan persediaan. PT. Cempaka Indah Murni Manado merupakan perusahaan dagang yang cukup besar yang bergerak dalam bidang distributor obat-obatan. Kelangsungan aktivitas usahanya membutuhkan persediaan obat yang jumlahnya tidak sedikit. Tingkat aktivitas perusahaan yang sangat tinggi dalam melakukan kegiatan jual beli menyebabkan kualitas obat menjadi sangat penting untuk diperhatikan oleh perusahaan. Perusahaan harus mampu mengelola persediaan yang dimiliki sebaik mungkin yang sesuai dengan Pernyataan Standar Akuntansi Keuangan (PSAK). Agar dapat terlaksana penyelenggaraan persediaan yang baik, maka perlu 
sistem akuntansi yang mendorong terciptanya keamanan, informasi yang akurat dan pertanggungjawaban.

Penerapan sistem akuntansi yang benar maka akan menghasilkan informasi akuntansi yang dapat dijadikan sebagai alat untuk menciptakan pengawasan intern yang baik. Pengawasan terhadap persediaan harus dapat memberikan keyakinan, bahwa data yang mengenai persediaan dapat dipercaya baik dari segi fisik, jumlah, kualitas, harga maupun pencatatannya. Persediaan juga memiliki pengaruh terhadap laporan keuangan suatu perusahaan. Maka itu perusahaan harus menerapkan Standar Akuntansi Keuangan (SAK) yaitu Pernyataan Standar Akuntansi Keuangan (PSAK) No. 14 yang membahas tentang Persediaan. Standar yang telah ditetapkan ini harus diterapkan dalam akuntansi persediaan pada setiap perusahaan yang memiliki persediaan.

\section{TINJAUAN PUSTAKA}

Definisi akuntansi. Menurut Suwardjono (2014:10), akuntansi dideskripsikan sebagai seperangkat alat yang mempelajari implementasi penyedia jasa berupa laporan keuangan kuantitatif bagian organisasi dalam suatu lingkup negara tertentu dengan cara penyajian (pelaporan) informasi tersebut kepada kelompok yang berkepentingan untuk dijadikan alasan dalam pengambilan hasil ekonomi. Menurut Jusup (2015:10), akuntansi adalah suatu kegiatan jasa, yang fungsinya menyediakan informasi kuantitatif, terutama yang bersifat keuangan tentang entitas ekonomi yang dimaksudkan agar berguna dalam mengambil keputusan ekonomi - membuat pilihan - pilihan nalar di antara berbagai alternatif tindakan. Menurut Warren et al. (2018:9) secara umum, akuntansi (accounting) dapat diartikan sebagai sistem informasi yang menyediakan laporan keuangan untuk para pemangku kepentingan mengenai aktivitas ekonomi dan kondisi perusahaan. Menurut Kieso et al. (2018:2), akuntansi terdiri dari tiga kegiatan yang mendasar yaitu identifikasi, pencatatan dan pengkomunikasian peristiwa ekonomi suatu organisasi kepada pihak yang berkepentingan. Perusahaan mengidentifikasi peristiwa ekonomi sesuai dengan kegiatan usahanya dan mencatat peristiwa tersebut untuk menyediakan catatan kegiatan keuangan. Pencatatan dilaksanakan secara sistematis, kronologis setiap peristiwa, dalam satuan mata uang. Akhirnya pada pengkomunikasian kumpulan informasi tersebut kepada pihak yang berkepentingan dalam bentuk laporan akuntansi atau dikenal dengan laporan keuangan. Menurut Kartikahadi et al. (2016:3), akuntansi adalah suatu sistem informasi keuangan, yang bertujuan untuk menghasilkan dan melaporkan informasi yang relevan bagi berbagai pihak yang berkepentingan. Menurut Pura (2013:18), pengertian siklus akuntansi merupakan serangkaian kegiatan akuntansi yang dilakukan secara sistematika dimulai dari pencatatan akuntansi sampai dengan penutupan pembukuan.

Menurut Waluyo (2016:34), akuntansi keuangan berhubungan dengan unit ekonomi secara keseluruhan dalam bentuk laporan keuangan yang dimanfaatkan oleh berbagai pihak dalam pengambilan keputusan yang didasarkan pada Standar Akuntansi Keuangan (SAK) yang berlaku). Menurut Martani et al. (2015:8), akuntansi keuangan berorientasi pada pelaporan pihak eksternal. Beragamnya pihak eksternal dengan tujuan spesifik bagi masingmasing pihak membuat pihak penyusun laporan keuangan menggunakan prinsip dan asumsiasumsi dalam penyusunan laporan keuangan. Diperlukan standar akuntansi yang dijadikan pedoman baik oleh penyusun maupun oleh pembaca laporan keuangan. Laporan yang dihasilkan dari akuntansi keuangan berupa laporan keuangan untuk tujuan umum. Menurut Warren et al. (2018:22) laporan keuangan adalah laporan akuntansi yang menyediakan informasi yang didapatkan setelah transaksi dicatat dan dirangkum. Merurut Hery dan Lekok (2017:2), dalam Standar Akuntansi Keuangan dijelaskan tentang tujuan laporan keuangan adalah menyediakan informasi yang menyangkut posisi keuangan, kinerja, serta perubahan 
posisi keuangan suatu perusahaan yang bermanfaat bagi sejumlah besar pemakai dalam pengambilan keputusan ekonomi.

Menurut Kieso et al. (2018:408) persediaan adalah aset yang dimiliki perusahaan dan tersedia untuk dijual dalam kepentingan bisnis atau merupakan barang yang akan digunakan untuk memproduksi barang yang tersedia untuk dijual. Persediaan merupakan suatu komponen aset yang sangat penting bagi perusahaan karena persediaan merupakan sumber utama dalam merealisasi laba perusahaan. Menurut Mulyadi (2016:99) yang dimaksud dengan persediaan adalah barang-barang yang dibeli perusahaan dengan maksud untuk dijual lagi (barang dagangan), atau masih dalam proses produksi yang akan diolah lebih lanjut menjadi barang jadi kemudian dijual (barang dalam proses) atau akan dipergunakan dalam proses produksi barang jadi yang kemudian dijual (bahan baku/ pembantu).

Jenis-jenis persediaan. Menurut Mulyadi (2016: 99), persediaan barang dagangan terdapat pada jenis perusahaan perdagangan yang kegiatan utamanya membeli dan menjual barang dagangan. Sedangkan persediaan bahan baku/pembantu, barang dalam proses dan barang jadi terdapat pada jenis perusahaan manufaktur yang mempunyai kegiatan utama mengelola bahan baku menjadi barang jadi. Menurut Halim dan Kusufi (2012:22) dalam perusahaan manufaktur terdapat tiga jenis persediaan, ketiga jenis persediaan itu adalah :

a. Persediaan Bahan Baku (bahan mentah), persediaan bahan baku merupakan bahan baku yang belum diusahakan untuk diproses didalam produksi.

b. Persediaan Barang (produk) Dalam Proses. Persediaan barang dalam proses merupakan bahan (material) yang belum selesai diproses produksi.

c. Persediaan Barang (produk) Jadi/Selesai, Persediaan barang jadi merupakan material atau barang yang sudah selesai diproduksi dan telah siap untuk dijual atau dikirim kepada langganan atau pemesan.

Menurut Supriyono (2010:16), harga pokok penjualan adalah jumlah yang dapat diukur dalam satuan uang, dalam bentuk kas yang dibayarkan atau nilai jasa yang diserahkan/dikorbankan, atau hutang yang timbul atau tambahan modal dalam rangka kepemilikan barang dan jasa diperlukan perusahaan, baik pada masa lalu maupun pada masa mendatang. Menurut PSAK No. 14, jika barang dalam persediaan dijual, maka nilai tercatat persediaan tersebut harus diakui sebagai beban pada periode diakuinya pendapatan atas penjualan tersebut. Proses pengakuan nilai tercatat persediaan yang telah dijual sebagai beban menghasilkan pengaitan (matching) beban dengan pendapatan. Oleh karena itu dalam menentukan besarnya laba harus dihitung terlebih dahulu besarnya harga pokok penjualan.

Menurut Gerungan et al. (2017) terdapat dua jenis metode pencatatan persediaan yaitu: (1) metode fisik, dimana dalam metode ini pencatatan mengenai jumlah persediaan tidak dilakukan secara terus menerus. Jumlah persediaan dicatat setiap akhir periode (misalnya akhir bulan atau akhir tahun), dengan jalan menghitung jumlah fisik persediaan yang ada pada akhir periode; dan (2) metode perpetual dalam metode ini pencatatan mengenai jumlah persediaan dilakukan secara terus-menerus, sehingga jumlah persediaan yang ada setiap saat dapat diketahui.

Metode Penilaian Persediaan yaitu: (1) metode FIFO adalah metode penentuan persediaan yang didasarkan pada anggapan bahwa barang yang paling dahulu dibeli (masuk) adalah yang paling dahulu dijual (dikeluarkan). Dengan demikian barang-barang yang ada dalam persediaan, dianggap berasal dari pembelian-pembelian yang terakhir karena barangbarangyang berasal dari pembelian-pembelian sebelumnya dianggap telah dijual (dikeluarkan); dan (2) metode FIFO didasarkan pada asumsi bahwa unit yang terjual adalah unit yang lebih dahulu masuk.

Pernyataan Standar Akuntansi Keuangan Nomor 14 (PSAK No.14) tentang Persediaan PSAK adalah standar yang harus diikuti dalam pencatatan dan pelaporan 
akuntansi di Indonesia. PSAK ini merupakan aturan-aturan yang harus ditaati oleh para akuntan agar pelaporan akuntansi di Indonesia ini menjadi lebih efektif.

a. Persediaan. Dalam PSAK Nomor.14 ini, Ikatan Akuntansi Indonesia mengkhususkan pernyataannya mengenai persediaan.Ini terdiri dari bagian pendahuluan, penjelasan dan mengungkapan mengenai persediaan barang dagangan.

b. Pendahuluan. Dalam pendahuluan PSAK Nomor.14 memuat tentang tujuan pernyataan, ruang lingkup pernyataan dan definisi persediaan. Pendahuluan ini terdiri dari paragraf 1 sampai dengan paragraf 4.

c. Tujuan. Tujuan pernyataan ini adalah untuk merumuskan perlakuan akuntansi untuk persediaan menurut sistem biaya historis. Permasalahan pokok dalam akuntansi persediaan adalah jumlah biaya yang harus diakui sebagai aset dan konversi selanjutnya sampai pendapatan yang bersangkutan diakui.

d. Ruang lingkup. Dalam paragraf 1 PSAK Nomor. 14 mengatakan bahwa: pernyataan ini harus diaplikasikan dalam penyusunan laporan keuangan dalam konteks sistem biaya historis tentang akuntansi persediaan selain: (1) pekerjaan dalam proses yang timbul dalam kontrak konstruksi (construction contracts); (2) instrumen keuangan; dan analisis penerapan metode; dan (3) persediaan yang dimiliki oleh produsen peternakan, produk pertanian dan kehutanan, dan hasil tambang sepanjang persediaan tersebut dinilai berdasarkan nilai realisasi bersih sesuai dengan kelaziman praktek yang berlaku dalam industri tertentu.

Barchelino (2016) mengemukakan bahwa pengungkapan persediaan sesuai dengan standar akuntansi yang berlaku di Indonesia yaitu PSAK Nomor.14 sehingga dalam kebijakan perusahaan dalam metode pencatatan dan penilaian persediaan barang dagang pada PT. Surya Wenang Indah Manado telah sesuai dengan standar akuntansi keuangan PSAK No. 14 tentang persediaan. Anwar dan Karamoy (2014) mengungkapkan bahwa metode pencatatan dan penilaian terhadap persediaan barang menurut PSAK Nomor 14 pada menunjukkan bahwa prosedur pengendalian internal persediaan barang dagang dan pengelolaan persediaan barang dagang terbilang baik sehinggah perusahaan mengetahui bagaimana peranan efektivitas pengendalian internal persediaan terhadap pengelolaan persediaaan barang dagang pada PT. Tirta Investama DC Manado. Manengkey (2014) menunjukan bahwa secara keseluruhan sistem pengendalian intern persediaan barang dagangan pada PT. Cahaya Mitra Alkes berjalan cukup efektif. Sehingga perusahaan mengetahui efektifitas pengendalian interen persediaan barang dagang dan penerapan akuntansinya. Sandiri et al. (2019) menunjukkan bahwa persediaan obat untuk penentuan harga pokok penjualan pada PT. Cempaka Indah Murni Manado sudah sesuai tapi perusahaan tidak mengakui adanya pembelian dan biaya angkut, perusahaan hanya mengakui adanya transfer masuk.

\section{METODE PENELITIAN}

Jenis penelitian yang digunakan yaitu penelitian metode deskriptif kualitatif karena peneilitian ini memakai fakta untuk memperoleh kesimpulan dari penelitian dan saran dalam rangka mengetahui dan memahami metode pencatatan penerapan akuntansi persediaan obat sesuai dengan Pernyataan Standar Akuntansi Keuangan (PSAK) No. 14 PT. Cempaka Indah Murni Manado.

Penelitian ini dilakukan pada PT. Cempaka Indah Murni Manado yang bertempat di J1. Raya Sea No. 140, Lingkungan V, Malalayang 1 Barat, Manado - 95262. Data kualitatif adalah data yang dinyatakan dalam bentuk kata, kalimat dan gambar PT. Cempaka Indah Murni Manado. Data kualitatif diperoleh melalui wawancara, observasi, diskusi atau pengamatan dari PT. Cempaka Indah Murni Manado. Data kualitatif pada penelitian ini berupa data-data mengenai akuntansi persediaan dan laporan keungan perusahaan. Data kuantitatif adalah data yang berbentuk angka, atau data kualitatif yang dikuantifikasikan. 
Sumber data yang digunakan pada penelitian ini adalah data primer sekunder. Data primer dalam penelitian ini adalah hasil wawancara langsung dengan pimpinan perusahaan, bagian akuntansi dan apoteker di PT. Cempaka Indah Murni Manado. Data sekunder yaitu menggunakan studi pustaka yang dilakukan dengan mengumpulkan, membaca, dan mempelajari literatur dan buku-buku serta referensi yang berhubungan dengan penelitian. Penelitian ini menggunakan metode pengumpul data dalam bentuk: wawancara, tinjauan pustaka dan observasi. Penelitian ini menggunakan metode analisis deskriptif. Proses analisis yang dilakukan oleh peneliti yaitu: mengumpulkan dan mempelajari informasi, menyusun data-data yang diperoleh dari PT Cempaka Indah Murni Manado.

\section{HASIL PENELITIAN DAN PEMBAHASAN}

\subsection{Hasil penelitian}

Hasil penelitian yang dilakukan pada PT. Cempaka Indah Murni Manado mengenai penerapan akuntansi persediaan apakah sudah sesuai dengan pernyataan standar akuntansi keuangan (PSAK) No. 14 ditemukan bahwa dalam metode pencatatan persediaannya ada yang tidak sesuai dengan Pernyataan Standar Akuntansi Keuangan (PSAK) No. 14. Pengukuran persediaan dalam perusahaan tidak mengakui adanya biaya pembelian. Perusahaan hanya mengakui, transaksi transfer masuk barang, biaya pengiriman/ekspedisi, dan biaya penjualan. Penilaian terhadap persediaan barang PT. Cempaka Indah Murni Manado menggunakan metode FIFO (First In, First Out). PT. Cempaka Indah Murni Manado melakukan pengakuan sebagai beban pada saat terjadi penjualan barang, yang dicatat dalam jurnal sebagai berikut:

Harga Pokok Penjualan Rp. xxx

Persediaan Barang Dagang Rp. Xxx

Aktivitas perusahaan tentang persediaan barang dagang diungkapkan melalui laporan keuangan perusahaan (neraca) dan laporan laba rugi perusahaan.

\section{PT. Cempaka Indah Murni Manado \\ Neraca \\ Per 31 Desember 2018}

ASET

LIABILITAS DAN EKUITAS

\begin{tabular}{|c|c|c|c|c|c|c|}
\hline & \multirow[t]{2}{*}{ ASET } & & \multicolumn{4}{|c|}{ LIABILITAS DAN EKUTTAS } \\
\hline Aset Lancar & & \multicolumn{5}{|c|}{ Kewajiban Lancar } \\
\hline Kas & $\mathrm{Rp}$ & 1.717.258.014,42 & Hutang Dagang & $\mathrm{Rp}$ & $\mathrm{xxx}$ & \\
\hline Piutang Dagang & $\mathrm{Rp}$ & $2.574 .747 .083,21$ & Hutang Lain-lain & $\mathrm{Rp}$ & $\mathrm{xxx}$ & \\
\hline Persediaan & $\mathrm{Rp}$ & $4.545 .312 .312,68$ & Hutang Pajak & $\mathrm{Rp}$ & $\mathrm{xxx}$ & \\
\hline Total Aset Lancar & $\mathrm{Rp}$ & $8.837 .317 .410,31$ & Total Kewajiban & $\mathrm{Rp}$ & & $\mathrm{xxx}$ \\
\hline Aset Tetap & & & & & & \\
\hline Peralatan & $\mathrm{Rp}$ & $\mathrm{XXX}$ & Modal & $\mathrm{Rp}$ & $\mathrm{XxX}$ & \\
\hline Ak. Peny. Peralatan & $\mathrm{Rp}$ & $(\mathrm{xxx})$ & Total Modal & $\mathrm{Rp}$ & & $\mathrm{xxx}$ \\
\hline Gedung & $\mathrm{Rp}$ & $\mathrm{xxx}$ & & & & \\
\hline Ak. Peny. Gedung & $\mathrm{Rp}$ & $(\mathrm{xxx})$ & & & & \\
\hline Total Aset Tetap & & $\mathrm{xxx}$ & & & & \\
\hline Total Aset & $\mathbf{R p}$ & 8.837.317.410,31 & Total liabilitas dan ekuitas & $\mathbf{R p}$ & & $\mathbf{X X X}$ \\
\hline
\end{tabular}




\section{PT. Cempaka Indah Murni Manado \\ Laba Rugi \\ Per 31 Desember 2018}

Penjualan

Harga PokokPenjualan

Persediaan Awal

Transfer Masuk

Barang yang tersedia untuk dijual

Persediaan Akhir

Laba Kotor
$\mathrm{Rp}$

4.093.943.609,42

\begin{tabular}{lr}
$R p$ & $364.968 .192,77$ \\
$R p$ & $3.644 .015 .532,88$ \\
\hline$R p$ & $4.008 .983 .725,65$ \\
$R p$ & $4.545 .312 .312,68$ \\
\hline
\end{tabular}

$\mathrm{Rp}$

$536.328 .587,03$

3.557.615.022,39

\subsection{Pembahasan}

Pengukuran Persediaan Barang di PT. Cempaka Indah Murni Manado hanya meliputi biaya lain-lain yaitu transaksi transfer masuk barang, biaya pengiriman/biaya ekspedisi, dan biaya penjualan. Pengukuran persediaan barang dagangan untuk mendapatkan harga pokok penjualan terdapat metode pencatatan persediaan dimana kebijakan manajemen PT. Cempaka Indah Murni Manado menerapkan metode pencatatan perpetual. Persediaan meliputi barang yang dibeli dan dijual kembali, persediaan juga meliputi barang jadi yang diproduksi, atau barang dalam penyelesaian yang sedang diproduksi oleh entitas serta termasuk bahan serta perlengkapan yang akan digunakan dalam proses produksi.

PT. Cempaka Indah Murni Manado melakukan pengakuan sebagai beban pada saat terjadi penjualan barang. Pengungkapan terhadap aktivitas perusahaan tentang persediaan barang dagang diungkapkan melalui laporan keuangan perusahaan (neraca) dan laporan laba rugi perusahaan. Laporan keuangan mengungkapkan: Kebijakan akuntansi yang digunakan dalam pengukuran persediaan, termasuk rumus biaya yang digunakan, total jumlah tercatat persediaan dan jumlah tercatat menurut klasifikasi yang sesuai bagi entitas. Tabel 1 menunjukan bahwa secara keseluruhan PT. Cempaka Indah Murni Manado telah sesuai dengan PSAK Nomor 14 dalam metode pencatatan, penilaian, persediaan, pengukuran maupun pengungkapan persediaan. 


\begin{tabular}{|c|c|c|}
\hline \multicolumn{3}{|c|}{ Tabel 1 Perbandingan Pencatatan Pada Perusahaan dan PSAK Nomor. 14} \\
\hline $\begin{array}{c}\text { Metode } \\
\text { Pencatatan } \\
\end{array}$ & $\begin{array}{c}\text { Perusahaan PT. Cempaka Indah Murni } \\
\text { Manado }\end{array}$ & PSAK No. 14 \\
\hline \multirow{15}{*}{ Pencatatan } & Transaksi Transfer Masuk Barang & Pembelian Persediaan Barang \\
\hline & Persediaan barang dagang barang Rp.xxx & Persediaan barang dagang Rp.xxx \\
\hline & Kas Rp.xxx & Kas Rp.xxx \\
\hline & Penggunaan Persediaan Barang Dagangan & Penggunaan Persediaan Barang \\
\hline & Barang dalam proses $\quad$ Rp.xxx & Barang dalam proses $\quad$ Rp.xxx \\
\hline & Persediaan barang dagang Rp.xxx & Persediaan Barang \\
\hline & $\begin{array}{l}\text { Pemindahan barang dalam proses ke } \\
\text { gudang penyimpanan }\end{array}$ & $\begin{array}{l}\text { Pemindahan barang dalam proses ke } \\
\text { gudang penyimpanan }\end{array}$ \\
\hline & Persediaan barang $\quad$ Rp.xxx & Persediaan barang $\quad$ Rp.xxx \\
\hline & Barang dalam proses & Barang dalam proses $\quad$ Rp.xxx \\
\hline & Pengiriman Barang Dagangan & Pengiriman Barang Dagangan \\
\hline & Piutang dagang $\quad$ Rp.xxx & Piutang Dagang $\quad$ Rp.xxx \\
\hline & Penjualan & Penjualan \\
\hline & Biaya Pengiriman/Biaya Ekspedisi & Biaya Angkut/Biaya Transportasi \\
\hline & Biaya Ekspedisi $\quad$ Rp xxx & Biaya Transportasi $\quad$ Rp.xxx \\
\hline & Piutang Dagang & $\begin{array}{ll}\text { Piutang Dagang } & \text { Rp.xxx }\end{array}$ \\
\hline $\begin{array}{l}\text { Pengukuran } \\
\text { Persediaan }\end{array}$ & Biaya lain-lain & $\begin{array}{l}\text { Biaya Pembelian, Biaya Konversi, Biaya } \\
\text { lain-lain }\end{array}$ \\
\hline Metode & First In, First Out (FIFO) & First In, First Out/ Last In, Last Out \\
\hline Penilaian & Masuk Pertama Keluar Pertama (MPKP) & $\begin{array}{l}\text { Masuk Pertama Keluar Pertama/ Masuk } \\
\text { Terakhir, Keluar Terakhir }\end{array}$ \\
\hline Pengakuan & Harga Pokok Penjualan $\quad$ Rp.xxx & Harga Pokok Penjualan $\quad$ Rp.xxx \\
\hline sebagai biaya & Persediaan barang dagang Rp.xxx & Persediaan barang dagangan Rp.xxx \\
\hline
\end{tabular}

\section{KESIMPULAN DAN SARAN}

\subsection{Kesimpulan}

Berdasarkan evaluasi akuntansi persediaan apakah sesuai dengan Pernyataan Standar Akuntansi Keuangan No. 14 pada PT. Cempaka Indah Murni Manado, maka dapat disimpulkan sebagai berikut: (1) pengukuran persediaan, dalam pengukuran persediaan pada PT. Cempaka Indah Murni Manado yang merupakan perusahaan dagang, jenis perusahaan yang usaha utamanya adalah distributor barang atau obat-obatan. Pengalokasian jumlah harga pokok penjualan dan biaya persediaan PT. Cempaka Indah Murni Manado menerapkan perhitungan dan pencatatan yang sesuai dengan PSAK No. 14 yaitu Metode FIFO (First In,First Out). Perusahaan tidak mengakui adanya biaya pembelian dan biaya konversi, perusahaan hanya mengakui biaya lain-lain seperti biaya pengiriman/biaya ekspedisi, transfer masuk, dan biaya penjualan; (2) pengakuan sebagai beban pada PT. Cempaka Indah Murni Manado melakukan pengakuan sebagai beban yaitu pada saat terjadi penjualan barang; (3) pengungkapan, dalam pengungkapan persediaan PT. Cempaka Indah Murni Manado disajikan dalam laporan keuangan yakni neraca dan laporan laba rugi; (4) hasil penelitian menunjukan penerapan akuntansi persediaan obat yang dilakukan. PT. Cempaka Indah Murni Manado tidak sesuai dengan PSAK No. 14. Perusahaan tidak mengakui adanya biaya pembelian dan biaya konversi, perusahaan hanya mengakui biaya lain-lain seperti biaya pengiriman/biaya ekspedisi, transfer masuk, dan biaya penjualan karena produk yang dijual di PT. Cempaka Indah Murni Manado dikirim dari kantor pusat yang berada di Surabaya.

\subsection{Saran}

Berdasarkan hasil penelitian, saran yang dapat diberikan pada PT. Cempaka Indah Murni Manado adalah: (1) sebaiknya perusahaan harus menerapkan biaya pengukuran 
persediaan secara keseluruhan yaitu biaya pembelian dan biaya konversi, agar pencatatan akuntansi dalam perusahaan berjalan sesuai dengan Pernyataan Standar Akuntansi Keuangan (PSAK No. 14); dan (2) pengembangan sistem infromasi, disarankan agar perusahaan memiliki aplikasi yang dirancang khusus untuk pencatatan akuntansi perusahaan, agar memudahkan perusahaan serta meminimalisir adanya kesalahan pencatatan.

\section{DAFTAR PUSTAKA}

Anwar, N. F., \& Karamoy, H. (2014). Analisis penerapan metode pencatatan dan penilaian terhadap persediaan barang menurut PSAK No. 14 pada PT. Tirta Investama DC Manado. Jurnal Emba: Jurnal Riset Ekonomi Manajemen Bisnis dan Akuntansi, 2(2), 1296-1305. https://ejournal.unsrat.ac.id/index.php/emba/article/view/4715

Barchelino, R. (2016). Analisis penerapan PSAK No.14 terhadap metode pencatatan dan penilaian persediaan barang dagangan pada PT. Surya Wenang Indah Manado. Jurnal EMBA: Jurnal Riset Ekonomi Manajemen Bisnis dan Akuntansi, 4(1), 837-846. https://ejournal.unsrat.ac.id/index.php/emba/article/view/11812

Gerungan, D., Pangemanan, S. S., \& Pusung, R. J. (2017). Evaluasi perlakuan persediaan barang dagangan pada PT. Pertani (PERSERO) Cabang Sulawesi Utara. Jurnal Riset Akuntansi Going Concern, 12(01), 118-129. https://doi.org/10.32400/gc.12.01.17144.2017

Halim, A., \& Kusufi, M. S. (2012). Akuntansi sektor publik: Akuntansi keuangan daerah. Edisi 4. Jakarta: Salemba Empat.

Hery \& Lekok, W. (2017). Akuntansi keuangan menengah 2. Jakarta : PT. Bumi Aksara.

Jusup, H. (2015). Dasar-dasar akuntansi. Edisi 7 Jilid 1. Yogyakarta: Sekolah Tinggi Ilmu Ekonomi YKPN.

Kartikahadi, H., Sinaga, R. U., Syamsul M., Siregar S. V., \& Wahyuni, E. T. (2016). Akuntansi keuangan: Berdasarkan SAK berbasis IFRS, Edisi 2 Buku 1. Jakarta: Ikatan Akuntan Indonesia.

Kieso, D. E., Weigandt, J. J., \& Warfield, T. D. (2018). Akuntansi keuangan menengah: Akuntansi intermediate. Edisi IFRS. Jakarta: Salemba Empat.

Manengkey, N. (2014). Analisis pengendalian intern persediaan barang dagang dan penerapan akuntansi pada PT. Cahaya Mitra Alkes. Jurnal EMBA: Jurnal Riset Ekonomi Manajemen Bisnis dan Akuntansi, 2(3), 13-21. https://ejournal.unsrat.ac.id/index.php/emba/article/view/5065

Martani, D., Siregar, S. V., Wardhani, R., Faramita, A., \& Tanujaya, E. (2015). Akuntansi keuangan menengah berbasis PSAK, Buku 2. Jakarta: Salemba Empat.

Mulyadi. (2016). Sistem akuntansi. Jakarta: Salemba Empat.

Pura, R. (2013). Pengantar akuntansi 1: Pendekatan siklus akuntansi. Jakarta: Erlangga.

Warren, C. S., Reeve, J. M., Duchac, J. E., Wahyuni, E. T., \& Jusuf, A. A. (2018). Pengantar akuntansi 2 (Adaptasi Indonesia), Edisi 4. Jakarta: Salemba Empat.

Suwardjono. (2014). Teori akuntansi perekayasaan pelaporan keuangan. Edisi Ketiga. Yogyakarta: Badan Penerbitan Fakultas Ekonomi.

Waluyo. (2016). Akuntansi pajak. Jakarta: Salemba Empat.

Sandiri, P. M., Ilat, V., \& Pinatik, S. (2019). Evaluasi penerapan akuntansi persediaan obat untuk penentuan harga pokok penjualan pada PT. Cempaka Indah Murni Manado. Jurnal Riset Akuntansi Going Concern, 14(1), 142-147. https://doi.org/10.32400/gc.14.1.22323.2019

Supriyono, R. A. (2010). Akuntansi biaya: Pengumpulan biaya dan penentuan harga pokok, Buku Pertama Edisi Kedua. Yogyakarta: Badan Penerbitan Fakultas Ekonomi. 